\title{
Alcohol and the risk of colon and rectal cancer with mutations in the K-ras gene
}

Citation for published version (APA):

Bongaerts, B. W., de Goeij, A. F., van den Brandt, P. A., \& Weijenberg, M. P. (2006). Alcohol and the risk of colon and rectal cancer with mutations in the K-ras gene. Alcohol, 38(3), 147-154.

https://doi.org/10.1016/j.alcohol.2006.06.003

Document status and date:

Published: 01/01/2006

DOI:

10.1016/j.alcohol.2006.06.003

Document Version:

Publisher's PDF, also known as Version of record

\section{Please check the document version of this publication:}

- A submitted manuscript is the version of the article upon submission and before peer-review. There can be important differences between the submitted version and the official published version of record.

People interested in the research are advised to contact the author for the final version of the publication, or visit the DOI to the publisher's website.

- The final author version and the galley proof are versions of the publication after peer review.

- The final published version features the final layout of the paper including the volume, issue and page numbers.

Link to publication

\footnotetext{
General rights rights.

- You may freely distribute the URL identifying the publication in the public portal. please follow below link for the End User Agreement:

www.umlib.nl/taverne-license

Take down policy

If you believe that this document breaches copyright please contact us at:

repository@maastrichtuniversity.nl

providing details and we will investigate your claim.
}

Copyright and moral rights for the publications made accessible in the public portal are retained by the authors and/or other copyright owners and it is a condition of accessing publications that users recognise and abide by the legal requirements associated with these

- Users may download and print one copy of any publication from the public portal for the purpose of private study or research.

- You may not further distribute the material or use it for any profit-making activity or commercial gain

If the publication is distributed under the terms of Article $25 \mathrm{fa}$ of the Dutch Copyright Act, indicated by the "Taverne" license above, 


\title{
Alcohol and the risk of colon and rectal cancer with mutations in the $K$-ras gene
}

\author{
Brenda W.C. Bongaerts ${ }^{\mathrm{a}, *}$, Anton F.P.M. de Goeij ${ }^{\mathrm{b}}$, Piet A. van den Brandt ${ }^{\mathrm{a}}$, \\ Matty P. Weijenberg ${ }^{a}$ \\ ${ }^{\mathrm{a}}$ Nutrition and Toxicology Research Institute Maastricht (NUTRIM), Department of Epidemiology, \\ University Maastricht, P.O. Box 616, 6200 MD Maastricht, The Netherlands \\ ${ }^{\mathrm{b}}$ Research Institute Growth and Development (GROW), Department of Pathology, \\ University Maastricht, 6200 MD Maastricht, The Netherlands
}

Received 23 February 2006; received in revised form 24 May 2006; accepted 8 June 2006

\begin{abstract}
The first metabolite of alcohol, acetaldehyde, may trigger replication errors and mutations in DNA, which may predispose to developing colorectal cancer (CRC). In a prospective study on colon and rectal cancer, we investigated the following hypotheses: alcohol consumption is associated with an increased risk of mutations in the $K$-ras oncogene, and beer consumption is associated with an increased risk of $\mathrm{G} \rightarrow$ A mutations in this gene. Therefore, we studied the associations between consumption of alcohol and alcoholic beverages and the risk of CRC without and with specific $K$-ras gene mutations. In 1986, 120,852 men and women, aged 55-69 years, completed a questionnaire on risk factors for cancer. The case-cohort approach was used for data processing and analyses. After 7.3 years of follow-up, excluding the first 2.3 years, complete data from 4,076 subcohort members, 428 colon and 150 rectal cancer patients, were available for data analyses. Incidence rate ratios (RRs) and corresponding 95\% confidence intervals (95\% CIs) were estimated using Cox proportional hazards models. Compared to abstaining, a total alcohol consumption of $30.0 \mathrm{~g}$ /day and more was associated with the risk of colon and rectal cancer with and without a $K$-ras mutation in both men and women. Independent from alcohol intake, liquor consumption when compared to nonliquor consumption was associated with an increased risk of rectal cancer with a wild type $K$-ras in men (RR: 2.25, 95\% CI: 1.0-5.0). Beer consumption was not clearly associated with the risk of colon and rectal tumors harboring $\mathrm{G} \rightarrow \mathrm{A}$ mutations in the $K$-ras gene in men. This association could not be assessed in women because of sparse beer consumption. In conclusion, alcohol does not seem to be involved in predisposing to CRC through mutations in the $K$-ras gene, and specifically beer consumption is not associated with colon and rectal tumors harboring a $\mathrm{G} \rightarrow$ A mutation. (C) 2006 Elsevier Inc. All rights reserved.
\end{abstract}

Keywords: Alcohol; Colorectal cancer; K-ras mutations; Cohort study; The Netherlands

\section{Introduction}

Consumption of alcohol is well-known to be associated with several malignant and nonmalignant diseases. Although alcohol itself is not carcinogenic, there is increasing evidence that acetaldehyde, a cytotoxic, mutagenic, and carcinogenic metabolite of alcohol, rather than alcohol itself, is responsible for tumor enhancing effects (Salaspuro, 2003; Seitz et al., 2001). Acetaldehyde can bind to cellular proteins and DNA, and the additional formation of stable DNA adducts could trigger replication errors and mutations in tumor suppressor genes or oncogenes. Acetaldehyde may also interfere with DNA repair by inhibiting enzymes

\footnotetext{
* Corresponding author. Tel.: +31-43-3882236; fax: +31-43-3884128.

E-mail address: Brenda.Bongaerts@epid.unimaas.nl (B.W.C.
} Bongaerts). important to the repair of adducts caused by alkylating agents (Ahmed, 1995; Salaspuro, 2003; Seitz et al., 2001). Regarding these mechanisms, it is plausible to consider alcohol consumption as a possible risk factor for developing colorectal cancer (CRC).

Development of CRC is a multistep process, characterized by an accumulation of several genetic alterations driving normal colorectal mucosa to transform into highly malignant derivatives (Fearon \& Vogelstein, 1990; Vogelstein et al., 1988). An early event in colorectal tumorigenesis is often an activating mutation in the $K$-ras oncogene. $K$-ras mutations occur in $30-60 \%$ of colorectal carcinomas and are involved in the progression of small adenomas to the more clinically relevant larger adenomas. Therefore, $K$-ras mutations may be an important contributor to CRC development. Most $K$-ras mutations are $\mathrm{G} \rightarrow$ A transitions and $\mathrm{G} \rightarrow \mathrm{T}$ transversions (Brink et al., 2003; Fearon \& 
Vogelstein, 1990). Several studies have shown that patients with these types of $K$-ras point mutations have a poor prognosis and a high risk of recurrence of the disease (Cerottini et al., 1998; Span et al., 1996). Knowledge of the etiology of $K$-ras mutations arising in colorectal tumors may provide valuable clues for prevention strategies.

The association between alcohol consumption and CRC was long debated, and according to a recently published pooled analysis of eight prospective cohort studies, CRC risk is only increased when daily alcohol consumption levels exceed $30.0 \mathrm{~g}$ (Cho et al., 2004). This suggests that there may be a threshold in alcohol consumption above which the risk of CRC is increased. The role of different types of alcoholic beverages on the risk of CRC is less clear, although beer consumption has more consistently been implicated in the etiology of rectal cancer. In the past, beer in the Netherlands and in other European countries was contaminated with relatively large amounts of $N$-nitrosodimethylamine (NDMA) (mean $1.2 \mu \mathrm{g} / \mathrm{kg}$ ) (Spiegelhalder et al., 1979; Stephany \& Schuller, 1980). As such, beer drinking accounted for $90 \%$ of the NDMA intake in beer drinkers, whose total NDMA intake was as much as 10 times higher than that of nonbeer drinkers. Jacoby et al. (1992) have shown that nitrosamines have mutagenic properties and are able to induce mutations, especially $\mathrm{G} \rightarrow \mathrm{A}$ transitions in the $K$-ras gene in rodents. However, since 1979 , changes in the beer-brewing process have greatly decreased the NDMA contaminations in beers (Ellen \& Schuller, 1983). Yet it is likely that the adverse effects of NDMA still influences the risk of (rectal) cancer for up to 10 years later, and that this declines in the years thereafter.

Taking into account the mutagenic and carcinogenic potentials of acetaldehyde mentioned above, we hypothesized that alcohol consumption is associated with an increased risk of mutations in the $K$-ras oncogene involved in CRC. Hence, we examined the associations between consumption of alcohol and various alcoholic beverages and the risk of colon and rectal cancer with and without $K$-ras gene mutations. In a second hypothesis, we stated that beer consumption is associated with $\mathrm{G} \rightarrow \mathrm{A}$ mutations in the $K$-ras gene involved in CRC. To answer this hypothesis, we examined the associations between beer consumption and this specific type of $K$-ras mutation among the colon and rectal cancer cases in our study population.

\section{Materials and methods}

\subsection{Study population}

In September 1986, the Netherlands Cohort Study on diet and cancer was initiated. The study design has been described in detail elsewhere (Van den Brandt et al., 1990a). Briefly, the cohort included 58,279 men and 62,573 women, aged 55-69 years at baseline and originating from 204 municipal population registries throughout the country. All cohort members completed an extensive self-administered questionnaire on daily dietary habits during the year preceding the start of the study, lifestyle factors, and other risk factors for cancer. Newly diagnosed cancer cases in the entire cohort were identified through annual record linkage to the Netherlands Cancer Registry (NCR, comprising nine cancer registries in the Netherlands) and to the Netherlands nationwide registry of pathology (PALGA), a nationwide database of histo- and cytopathology reports, used for identification and location of tumor tissue from eligible CRC cases stored in 54 Dutch Pathology laboratories (Van den Brandt et al., 1990b).

These analyses were carried out over the 7.3-year period of follow-up since September 1986. The first 2.3 years of follow-up were excluded, due to incomplete coverage of PALGA in some of the municipalities included and since subclinical symptoms may have influenced the exposure status in cases diagnosed during these 2.3 years. Using updated information from the NCR in 2004, 925 cases with histologically confirmed CRC were identified with an incidence date between January 1989 and January 1994, of whom 815 could be linked to a PALGA report of the lesion. CRC was classified according to site as follows, colon: cecum through sigmoid colon (ICD-O codes 153.0, 153.1, 153.2, 153.3, 153.4, $153.5,153.6,153.7,153.8,153.9)$; rectosigmoid colon (ICD-O code 154.0); and rectum (ICD-O code 154.1).

Processing and analysis of data were done according to the case-cohort approach: cases were identified for the entire cohort, whereas a random sample of the cohort (subcohort) was used to estimate person years at risk accumulating in the cohort (from the date of entry into the cohort until the date of a CRC diagnosis, death from any cause, leaving the study area, or the end of the 7.3-year follow-up period). This subcohort of 5,000 men and women was followedup biennially to assess information on vital status and migration to calculate accumulated person time in the cohort. Prevalent cancer cases, other than nonmelanoma skin cancer were excluded from the subcohort, resulting in 4,748 subcohort members. During the first 2.3 years of followup, $101(2 \%)$ subcohort members deceased or were diagnosed with cancer other than nonmelanoma skin cancer, leaving 4,647 subcohort members for analysis.

\subsection{Assessment of exposure}

Information on daily dietary habits was obtained by a 150-item semiquantitative food frequency questionnaire. Alcohol consumption was measured by six items: (1) beer, (2) red wine, (3) white wine, (4) sherry and other fortified wines, (5) liqueur (containing 16\% alcohol), and (6) (Dutch) gin, brandy, and whiskey, which are presumed to cover all types of consumed alcoholic beverages. Participants were asked about their usual frequency of consumption (never/less than once per month, once per month, 2-3 times per month, once per week, 2-3 times per week, 4-5 times per week, and 6-7 times per week) and the number of glasses consumed at each drinking occasion. The total amount of alcohol per day ( $g /$ day) was calculated 
by using the reported frequency of consumption, the quantity consumed, and the alcohol content of the consumed beverage.

The questionnaire has been validated against a 9-day diet record (Van den Brandt et al., 1990a). The Spearman correlation coefficient between mean daily alcohol intake assessed by the questionnaire and estimated from the 9-day diet record was 0.89 for all subjects and 0.85 for users of alcoholic beverages. The absolute amount of alcohol reported in the questionnaire by users of alcoholic beverages was, on average, $86 \%$ of that reported in the 9-day diet record.

Next to the dietary section, the questionnaire comprised a section on lifestyle and other risk factors for cancer. Information on, for instance, family history of CRC, sex, age at baseline, smoking, and body mass index (BMI) were retrieved from this section.

\subsection{Tissue samples and molecular analyses}

Tumor material of CRC cases, identified in the entire cohort, was collected after approval of the Ethical Review Boards of University Maastricht, the NCR and PALGA. From $44(5 \%)$ of the eligible 815 CRC cases, tissue samples could not be retrieved. Of the retrieved 771 tissue samples, $37(5 \%)$ contained only healthy colorectal mucosa, did not yield sufficient DNA for molecular analyses, or were revised as a benign adenoma instead of a carcinoma by a pathologist. Hence, tumor tissue of $734 \mathrm{CRC}$ cases was available for molecular analyses.

Mutation analysis of the exon 1 fragment of the $K$-ras oncogene, spanning codons 8-29, was performed on archived adenocarcinoma specimens of all 734 CRC patients (Brink et al., 2003).

\subsection{Data analyses}

Data analyses were based on subcohort members and cases for whom information on alcohol consumption and confounding variables were complete, i.e., 4,076 subcohort members, 428 colon cancer cases, and 150 rectal cancer cases. Since the rectosigmoid can be considered as a clinically applied term rather than an anatomically defined transitional zone between the colon and the rectum, cases with a rectosigmoid tumor $(n=70)$ were excluded from data analyses. Moreover, the group of cases with a rectosigmoid tumor was too small for adequate stratified analyses. Incidence rate ratios (RRs) and corresponding 95\% confidence intervals (CIs) were estimated using Cox proportional hazards models. The proportional hazards assumption was tested using the scaled Schoenfeld residuals (Schoenfeld, 1982). Standard errors were estimated using the robust $\mathrm{Hu}-$ ber-White sandwich estimator to account for additional variance introduced by sampling from the cohort.

Next to considering total amount of alcohol consumption, we examined three types of alcoholic beverages, i.e., beer, wine (red wine, white wine, sherry, and other fortified wines), and liquor (liqueur, gin, brandy, and whiskey). An extensive categorization of the alcohol variables was not possible due to small numbers of cases per category. Only total alcohol consumption was divided into three categories: $0,<30.0$, and $\geq 30.0 \mathrm{~g} / \mathrm{day}$. The threshold value of $30.0 \mathrm{~g} /$ day was chosen in line with the results of the pooled analysis by Cho et al. (2004).

Data analysis was conducted separately for male and female colon and rectal cancer with and without a $K$-ras mutation, described here as $K$-ras + (tumors harboring a $K$-ras mutation) and $K$-ras - (tumors harboring a wild type $K$-ras gene). However, since several cells comprised less than 10 cancer cases and some reference groups comprised relatively small numbers of cases, analyses were also conducted for all male plus female CRC cases with and without a $K$-ras mutation. In the overall analyses only, the rectosigmoid cancer cases were included.

In the light of our second hypothesis, cases with a $K$-ras mutation were further examined for associations between beer consumption and the risk of colon and rectal cancer harboring a $\mathrm{G} \rightarrow$ A mutation in the $K$-ras gene.

Age at baseline (years), BMI $\left(\mathrm{kg} / \mathrm{m}^{2}\right)$, family history of CRC (yes vs. no), daily intake of total energy (kJ/day), daily folate intake ( $\mu \mathrm{g} /$ day), daily intake of linoleic acid (g/day) and calcium (mg/day), physical activity (min/ day), and smoking (never, ex, current) were considered as potential confounders. Those variables that changed the regression coefficient for alcohol by more than $10 \%$, or those that were found to statistically significantly contribute to the multivariable model for colon and rectal cancer were included in the analyses. Analyses for beer, wine, and liquor were additionally adjusted for total alcohol consumption (as a categorical variable), to evaluate the effect of the beverage on the risk of colon and rectal cancer independent of the beverage's alcoholic content. Interactions between sex and alcohol consumption were investigated as well as interactions between smoking and alcohol, and folate intake and alcohol, but none of the tested interactions were found to be statistically significant. $P$-values $<.05$ were considered statistically significant. All analyses were performed with the STATA statistical software package.

\section{Results}

Alcohol intake and baseline characteristics of the study population are presented in Table 1. Overall, both male and female colon and rectal cancer patients tended to be older in age than subcohort members. For female colon cancer cases, cases with a K-ras+ tumor were older in age than cases with a $K$-ras - tumor $(P<.05)$. Furthermore, for both men and women, there were no significant differences in alcohol consumption or lifestyle characteristics when comparing the $K$-ras- colon tumors with the $K$ ras + colon tumors or when comparing the $K$-ras - rectal tumors with the $K$-ras + rectal tumors.

Associations between drinking habits in men and the risk of $\mathrm{K}$-ras - and $\mathrm{K}$-ras + colon and rectal tumors are presented in Table 2. Consumption equal to or exceeding 
Table 1

Baseline characteristics and drinking habits (mean [S.D.]) of the study population by sex, tumor site, and $K$-ras status, the Netherlands Cohort Study (1986-1993)

\begin{tabular}{|c|c|c|c|c|c|c|c|c|c|c|}
\hline & \multicolumn{5}{|l|}{ Men } & \multicolumn{5}{|l|}{ Women } \\
\hline & \multirow[b]{2}{*}{ Subcohort } & \multicolumn{2}{|l|}{ Colon cancer } & \multicolumn{2}{|l|}{ Rectal cancer } & \multirow[b]{2}{*}{ Subcohort } & \multicolumn{2}{|l|}{ Colon cancer } & \multicolumn{2}{|l|}{ Rectal cancer } \\
\hline & & Wild type $K$-ras & Mutated $K$-ras & Wild type $K$-ras & Mutated $K$-ras & & Wild type $K$-ras & Mutated $K$-ras & Wild type $K$-ras & Mutated $K$-ras \\
\hline$N$ & 2,029 & 148 & 82 & 63 & 36 & 2,047 & 140 & 58 & 24 & 27 \\
\hline Age (years) & $61.3(4.2)$ & $62.5(4.2)$ & $63.4(4.2)$ & $62.4(4.1)$ & $62.3(4.0)$ & $61.4(4.3)$ & $62.7(4.3)^{\mathrm{a}}$ & $64.0(3.5)$ & $63.5(3.7)$ & $61.5(3.7)$ \\
\hline \multicolumn{11}{|l|}{ Alcohol consumption } \\
\hline Total alcohol (g/day) & $15.0(16.8)$ & $15.6(16.5)$ & $15.7(16.3)$ & $17.4(19.7)$ & $14.7(12.7)$ & $5.8(9.4)$ & $6.0(12.5)$ & $4.1(7.1)$ & $5.3(6.5)$ & $6.9(3.7)$ \\
\hline Beer (glasses/week) & $3.2(7.1)$ & $3.1(7.2)$ & $2.3(4.3)$ & $3.3(6.3)$ & $3.1(4.7)$ & $0.2(1.5)$ & $0.3(2.0)$ & $0.04(0.2)$ & $0.1(0.7)$ & $0.1(0.3)$ \\
\hline Wine (glasses/week) & $2.5(5.2)$ & $2.7(4.9)$ & $3.1(6.1)$ & $2.4(5.7)$ & $2.9(4.6)$ & $2.7(4.8)$ & $2.5(5.2)$ & $1.7(3.5)$ & $2.9(4.1)$ & $3.4(6.4)$ \\
\hline Liquor (glasses/week) & $4.1(6.4)$ & $4.3(6.5)$ & $4.5(6.4)$ & $5.8(8.7)$ & $3.7(4.9)$ & $0.9(2.8)$ & $1.1(4.4)$ & $1.0(2.5)$ & $0.4(1.1)$ & $0.9(2.1)$ \\
\hline \multicolumn{11}{|l|}{ Total alcohol (\%) } \\
\hline Abstainers & 14 & 15 & 16 & 11 & 11 & 33 & 37 & 46 & 38 & 26 \\
\hline $0.1-4.9 \mathrm{~g} /$ day & 21 & 24 & 23 & 25 & 22 & 36 & 35 & 28 & 21 & 41 \\
\hline $5.0-14.9 \mathrm{~g} /$ day & 27 & 22 & 20 & 21 & 17 & 19 & 13 & 15 & 33 & 18 \\
\hline $15.0-29.9 \mathrm{~g} /$ day & 23 & 22 & 23 & 21 & 36 & 9 & 9 & 9 & 8 & 11 \\
\hline$\geq 30.0 \mathrm{~g} /$ day & 15 & 17 & 18 & 22 & 14 & 3 & 6 & 2 & 0 & 4 \\
\hline \multicolumn{11}{|l|}{ Other characteristics: } \\
\hline Family history of CRC (\%) & 5.5 & 12.8 & 12.2 & 7.9 & 16.7 & 6.1 & 12.9 & 6.9 & 16.7 & 7.4 \\
\hline Body mass index $\left(\mathrm{kg} / \mathrm{m}^{2}\right)$ & $25.0(2.6)$ & $25.3(2.6)$ & $25.9(3.1)$ & $12.9(2.5)$ & $25.1(2.7)$ & $25.0(3.6)$ & $25.6(3.7)$ & $25.5(3.7)$ & $25.0(3.7)$ & $25.9(3.1)$ \\
\hline Calcium intake $(\mathrm{mg})^{\mathrm{b}}$ & 947 (293) & $976(3,001)$ & $930(277)$ & $933(214)$ & 843 (227) & $903(268)$ & 899 (256) & $913(254)$ & $1,005(342)$ & $860(214)$ \\
\hline Linoleic acid intake $(\mathrm{g})^{\mathrm{c}}$ & $16.2(8.2)$ & $16.7(7.7)$ & $18.3(7.8)$ & $17.1(8.4)$ & $17.0(9.1)$ & $12.7(6.2)$ & $11.9(5.9)$ & $13.6(6.6)$ & $11.4(5.2)$ & $11.4(5.3)$ \\
\hline \multicolumn{11}{|l|}{ Smoking (\%) } \\
\hline Never & 13 & 11 & 11 & 19 & 14 & 58 & 62 & 74 & 67 & 56 \\
\hline Exsmoker & 52 & 63 & 67 & 59 & 53 & 21 & 24 & 16 & 8 & 33 \\
\hline Current smoker & 35 & 26 & 22 & 32 & 33 & 21 & 14 & 10 & 25 & 11 \\
\hline
\end{tabular}

${ }^{a} \mathrm{P}<.05$, for comparisons between cases without and with a $K$-ras mutation.

${ }^{\mathrm{b}}$ Adjusted for energy intake from dairy products.

${ }^{\mathrm{c}}$ Adjusted for total energy intake. 
Table 2

$\mathrm{RRs}^{\mathrm{a}}$ for male colon and rectal cancer cases with a wild type or a mutated $K$-ras gene according to drinking habits, adjusted for confounders, the Netherlands Cohort Study (1986-1993)

\begin{tabular}{|c|c|c|c|c|c|c|c|c|c|}
\hline \multirow[b]{3}{*}{ Drinking habits } & \multirow[b]{3}{*}{$\begin{array}{l}\text { Person years } \\
\text { in subcohort }\end{array}$} & \multicolumn{4}{|c|}{ Colon cancer } & \multicolumn{4}{|c|}{ Rectal cancer } \\
\hline & & \multicolumn{2}{|c|}{ Wild type $K$-ras } & \multicolumn{2}{|c|}{ Mutated $K$-ras } & \multicolumn{2}{|c|}{ Wild type $K$-ras } & \multicolumn{2}{|c|}{ Mutated $K$-ras } \\
\hline & & $\begin{array}{l}\text { Number } \\
\text { of cases }\end{array}$ & $\operatorname{RR}(95 \% \mathrm{CI})^{\mathrm{a}}$ & $\begin{array}{l}\text { Number } \\
\text { of cases }\end{array}$ & $\operatorname{RR}(95 \% \mathrm{CI})^{\mathrm{a}}$ & $\begin{array}{l}\text { Number } \\
\text { of cases }\end{array}$ & $\operatorname{RR}(95 \% \mathrm{CI})^{\mathrm{a}}$ & $\begin{array}{l}\text { Number } \\
\text { of cases }\end{array}$ & $\operatorname{RR}(95 \% \mathrm{CI})^{\mathrm{a}}$ \\
\hline \multicolumn{10}{|c|}{ Total alcohol (g/day) } \\
\hline No alcohol & 2,035 & 22 & 1.00 & 13 & 1.00 & 7 & 1.00 & 4 & 1.00 \\
\hline$<30.0$ & 10,190 & 100 & $0.95(0.6-1.6)$ & 54 & $0.84(0.4-1.6)$ & 42 & $1.23(0.5-2.8)$ & 27 & $1.30(0.4-4.0)$ \\
\hline$\geq 30.0$ & 2,121 & 26 & $1.24(0.7-2.3)$ & 15 & $1.15(0.5-2.6)$ & 14 & $2.00(0.8-5.3)$ & 5 & $0.98(0.2-4.0)$ \\
\hline \multicolumn{10}{|l|}{ Beer $^{b}$} \\
\hline No beer & 6,082 & 69 & 1.00 & 40 & 1.00 & 30 & 1.00 & 14 & 1.00 \\
\hline Beer drinker & 8,264 & 79 & $0.84(0.6-1.2)$ & 42 & $0.78(0.5-1.3)$ & 33 & $0.68(0.4-1.2)$ & 22 & $1.09(0.5-2.4)$ \\
\hline \multicolumn{10}{|l|}{ Wine $^{b}$} \\
\hline No wine & 7,094 & 69 & 1.00 & 43 & 1.00 & 32 & 1.00 & 18 & 1.00 \\
\hline Wine drinker & 7,252 & 79 & $1.11(0.7-1.7)$ & 39 & $0.85(0.5-1.4)$ & 31 & $0.79(0.4-1.4)$ & 18 & $0.92(0.4-1.9)$ \\
\hline \multicolumn{10}{|l|}{ Liquor $^{\mathrm{b}}$} \\
\hline No liquor & 5,234 & 51 & 1.00 & 29 & 1.00 & 14 & 1.00 & 11 & 1.00 \\
\hline Liquor drinker & 9,112 & 97 & $1.08(0.7-1.7)$ & 53 & $0.97(0.5-1.7)$ & 49 & $2.25(1.0-5.0)$ & 25 & $1.15(0.5-2.7)$ \\
\hline
\end{tabular}

$\mathrm{RR}=$ incidence risk ratio; $\mathrm{CI}=$ Confidence interval

${ }^{a}$ Adjusted for age, family history of colorectal cancer (yes/no), body mass index ( $\left.\mathrm{kg} / \mathrm{m}^{2}\right)$, calcium intake (mg/day), linoleic intake (g/day), and smoking (never/ex/current).

${ }^{\mathrm{b}}$ Additionally adjusted for total alcohol consumption $(0,<30.0, \geq 30.0 \mathrm{~g} /$ day $)$.

$30.0 \mathrm{~g}$ of alcohol per day, compared to abstaining was associated with an increased risk of colon cancer with and without a $K$-ras mutation, although none of these results reached statistical significance. For rectal cancer, both with and without $K$-ras mutations, the reference group and the group of cases who consumed $30.0 \mathrm{~g}$ of alcohol per day or more was very small, making it difficult to interpret the results correctly. Most of the associations with the different beverage types adjusted for total alcohol consumption were not consistent, suggesting that in general no clear associations with $K$-ras - and $K$-ras + colon and rectal tumors existed. Compared to nonliquor consumers, liquor consumption was associated with an increased risk of a $K$-ras - rectal tumor, independent of the consumed alcohol (RR: 2.25 , 95\% CI: $1.0-5.0$ ).

Table 3 shows the associations between drinking habits in women and the risk of $K$-ras- and $K$-ras + colon and rectal tumors. When compared to abstaining, consumption of $30.0 \mathrm{~g}$ of alcohol per day and more was positively associated with $K$-ras - colon tumors. The $K$-ras + colon cancer subgroup and both rectal cancer subgroups comprised too few cases to adequately interpret the results for total alcohol consumption. The results for the different beverage types independent of alcohol content, suggested that there were no clear associations with the risk of colon and rectal cancer with and without a $K$-ras mutation.

For the overall analyses (Table 4), combining all male plus female CRC cases (including rectosigmoid cancer cases), results pointed in the same direction as the results for the stratified analyses presented in Tables 2 and 3. Compared to abstainers, an increased risk was observed for $K$ ras - and $K$-ras + colorectal tumors for cases whose daily consumption exceeded $30.0 \mathrm{~g}$ of alcohol. Independent of consumed alcohol, only liquor consumption was positively associated with the risk of $K$-ras- colorectal tumors, although statistical significance was not reached (RR: 1.22 , 95\% CI: $0.9-1.6$ ).

To examine the hypothesis that beer consumption is associated with $\mathrm{G} \rightarrow$ A mutations in the $K$-ras gene, a further distinction of $K$-ras + tumors was made into tumors with a $\mathrm{G} \rightarrow \mathrm{A}$ transition (results not shown). There were 41 male and 29 female colon cancer cases with a $\mathrm{G} \rightarrow$ A transition and 20 male and 9 female rectal cancer cases harboring this transition. When compared to the nonbeer drinkers, consumption of beer was not associated with the risk of colon tumors harboring a $\mathrm{G} \rightarrow$ A mutation in men, independent of the alcohol consumed. A positive association however was observed between beer drinking, independent of the alcohol consumed, and the risk of rectal tumors harboring a $\mathrm{G} \rightarrow \mathrm{A}$ mutation (RR: 3.48, 95\% CI: 1.1-11.0). In women, these associations could not be assessed since there were only two female colon cancer cases and no female rectal cancer cases harboring a $\mathrm{G} \rightarrow$ A mutation that consumed beer.

Next to beer intake, we also considered associations between total alcohol, wine, and liquor consumption and risk of colon and rectal tumors harboring $\mathrm{G} \rightarrow$ A mutations, but no significant relationships were found.

\section{Discussion}

\subsection{Alcohol, CRC, and K-ras gene mutations}

In the current prospective study, we have investigated associations between alcohol consumption and the risk of 
Table 3

$\mathrm{RRs}^{\mathrm{a}}$ for female colon and rectal cancer cases with a wild type or a mutated $K$-ras gene according to drinking habits, adjusted for confounders, the Netherlands Cohort Study (1986-1993)

\begin{tabular}{|c|c|c|c|c|c|c|c|c|c|}
\hline \multirow[b]{3}{*}{ Drinking habits } & \multirow[b]{3}{*}{$\begin{array}{l}\text { Person years } \\
\text { in subcohort }\end{array}$} & \multicolumn{4}{|c|}{ Colon cancer } & \multicolumn{4}{|c|}{ Rectal cancer } \\
\hline & & \multicolumn{2}{|c|}{ Wild type $K$-ras } & \multicolumn{2}{|c|}{ Mutated $K$-ras } & \multicolumn{2}{|c|}{ Wild type $K$-ras } & \multicolumn{2}{|c|}{ Mutated $K$-ras } \\
\hline & & $\begin{array}{l}\text { Number } \\
\text { of cases }\end{array}$ & $\operatorname{RR}(95 \% \mathrm{CI})^{\mathrm{a}}$ & $\begin{array}{l}\text { Number } \\
\text { of cases }\end{array}$ & $\operatorname{RR}(95 \% \mathrm{CI})^{\mathrm{a}}$ & $\begin{array}{l}\text { Number } \\
\text { of cases }\end{array}$ & $\operatorname{RR}(95 \% \mathrm{CI})^{\mathrm{a}}$ & $\begin{array}{l}\text { Number } \\
\text { of cases }\end{array}$ & $\operatorname{RR}(95 \% \mathrm{CI})^{\mathrm{a}}$ \\
\hline \multicolumn{10}{|c|}{ Total alcohol (g/day) } \\
\hline No alcohol & 4,727 & 52 & 1.00 & 27 & 1.00 & 9 & 1.00 & 7 & 1.00 \\
\hline$<30.0$ & 9,467 & 80 & $0.78(0.5-1.1)$ & 30 & $0.62(0.4-1.1)$ & 15 & $0.98(0.4-2.2)$ & 19 & $1.28(0.5-3.2)$ \\
\hline$\geq 30.0$ & 503 & 8 & $1.83(0.8-4.1)$ & 1 & $0.65(0.1-5.5)$ & 0 & - & 1 & $1.25(0.1-11.7)$ \\
\hline \multicolumn{10}{|l|}{ Beer $^{\mathrm{b}}$} \\
\hline No beer & 13,239 & 129 & 1.00 & 55 & 1.00 & 22 & 1.00 & 24 & 1.00 \\
\hline Beer drinker & 1,458 & 11 & $0.74(0.4-1.5)$ & 3 & $0.80(0.2-2.8)$ & 2 & $1.22(0.3-6.0)$ & 3 & $0.88(0.2-3.4)$ \\
\hline \multicolumn{10}{|l|}{ Wine $^{\mathrm{b}}$} \\
\hline No wine & 6,507 & 71 & 1.00 & 33 & 1.00 & 10 & 1.00 & 11 & 1.00 \\
\hline Wine drinker & 8,190 & 69 & $0.79(0.5-1.3)$ & 25 & $1.05(0.4-2.6)$ & 14 & $3.80(0.5-30.0)$ & 16 & $0.88(0.3-2.8)$ \\
\hline \multicolumn{10}{|l|}{ Liquor $^{\mathrm{b}}$} \\
\hline No liquor & 9,649 & 90 & 1.00 & 40 & 1.00 & 18 & 1.00 & 14 & 1.00 \\
\hline Liquor drinker & 5,048 & 50 & $1.16(0.7-1.8)$ & 18 & $1.20(0.6-2.5)$ & 6 & $0.56(0.2-1.7)$ & 13 & $1.72(0.7-4.4)$ \\
\hline
\end{tabular}

$\mathrm{RR}=$ incidence risk ratio; $\mathrm{CI}=$ confidence interval.

${ }^{\mathrm{a}}$ Adjusted for age, family history of colorectal cancer (yes/no), body mass index $\left(\mathrm{kg} / \mathrm{m}^{2}\right)$, calcium intake (mg/day), linoleic intake (g/day), and smoking (never/ex/current).

${ }^{\mathrm{b}}$ Additionally adjusted for total alcohol consumption $(0,<30.0, \geq 30.0 \mathrm{~g} /$ day $)$.

colon and rectal cancer with and without $K$-ras mutations, as our hypothesis implied a relationship between alcohol consumption and colorectal tumors harboring a $K$-ras mutation. When considering all male plus female colorectal tumors according to $K$-ras mutational status, our results showed that a daily alcohol consumption of $30.0 \mathrm{~g} /$ day and more was associated with an increased risk of CRC, which is consistent with current literature (Cho et al., 2004). However, in contradiction with our hypothesis this increase in risk was independent of the presence or absence of $K$-ras mutations. When stratifying by sex and tumor site, this result was still observed for subgroups with sufficient numbers of cases. No clear associations were seen between alcohol intakes below $30.0 \mathrm{~g} / \mathrm{day}$ and the risk of $\mathrm{K}$-rasand $K$-ras + colon and rectal tumors in both men and women. There is evidence that acetaldehyde is directly involved in CRC (Taylor \& Rehm, 2005), but also other mechanisms have been linked to colorectal tumorigenesis,

Table 4

$\mathrm{RRs}^{\mathrm{a}}$ for male and female CRC cases (including the rectosigmoid cancer cases) with a wild type or a mutated $K$-ras gene according to drinking habits, adjusted for confounders, the Netherlands Cohort Study (1986-1993)

\begin{tabular}{|c|c|c|c|c|c|}
\hline \multirow[b]{2}{*}{ Drinking habits } & \multirow{2}{*}{$\begin{array}{l}\text { Person years } \\
\text { in subcohort }\end{array}$} & \multicolumn{2}{|l|}{ Wild type $K$-ras } & \multicolumn{2}{|l|}{ Mutated $K$-ras } \\
\hline & & Number of cases & $\overline{\mathrm{RR}(95 \% \mathrm{CI})^{\mathrm{a}}}$ & Number of cases & $\mathrm{RR}(95 \% \mathrm{CI})^{\mathrm{a}}$ \\
\hline \multicolumn{6}{|c|}{ Total alcohol (g/day) } \\
\hline No alcohol & 6,761 & 96 & 1.00 & 56 & 1.00 \\
\hline$<30.0$ & 19,656 & 272 & $0.94(0.7-1.2)$ & 147 & $0.85(0.6-1.2)$ \\
\hline$\geq 30.0$ & 2,624 & 49 & $1.25(0.8-1.8)$ & 28 & $1.13(0.7-1.9)$ \\
\hline \multicolumn{6}{|l|}{ Beer $^{\mathrm{b}}$} \\
\hline No beer & 19,321 & 278 & 1.00 & 152 & 1.00 \\
\hline Beer drinker & 9,722 & 139 & $0.84(0.6-1.1)$ & 79 & $0.86(0.6-1.2)$ \\
\hline \multicolumn{6}{|l|}{ Wine $^{\mathrm{b}}$} \\
\hline No wine & 13,601 & 202 & 1.00 & 117 & 1.00 \\
\hline Wine drinker & 15,441 & 215 & $0.92(0.7-1.2)$ & 114 & $0.88(0.6-1.2)$ \\
\hline \multicolumn{6}{|l|}{ Liquor $^{\mathrm{b}}$} \\
\hline No liquor & 14,883 & 190 & 1.00 & 109 & 1.00 \\
\hline Liquor drinker & 14,159 & 227 & $1.22(0.9-1.6)$ & 122 & $1.07(0.8-1.5)$ \\
\hline
\end{tabular}

$\mathrm{RR}=$ incidence risk ratio; $\mathrm{CI}=$ confidence interval $\mathrm{CRC}=$ colorectal cancer.

${ }^{a}$ Adjusted for age, family history of CRC (yes/no), body mass index $\left(\mathrm{kg} / \mathrm{m}^{2}\right)$, calcium intake (mg/day), linoleic intake (g/day), and smoking (never/ex/ current).

${ }^{\mathrm{b}}$ Additionally adjusted for total alcohol consumption $(0,<30.0, \geq 30.0 \mathrm{~g} /$ day $)$. 
e.g., the induction of reactive oxygen species through the induction of cytochrome P-450 2E (Badger et al., 2003; Boffetta \& Hashibe, 2006; Seitz et al., 2005). Many of these processes have been observed in heavy or chronic alcohol consumers. The amount of alcohol-related damage tends to follow a dose-response relationship and as such, higher levels of daily alcohol intakes may be needed for genetic mutations to occur as a result of alcohol consumption. Moderate consumption levels, as in our study population, might not be able to increase CRC risk through causing specific gene mutations. This may explain why we do not observe a differential association between alcohol consumption and $K$-ras - and $K$-ras + tumors. Thus, moderate drinking apparently involves a certain risk of developing colorectal tumors, possibly arising through mechanisms other than those causative of genetic aberrations.

Liquor consumption as opposed to nonliquor consumption, increased the risk of a $K$-ras - rectal tumor in men independent of the alcohol consumed. Although this finding was statistically significant, we must warrant caution not to overinterpret this result. We performed many analyses and therefore it is possible that this is merely a chance finding. Moreover, the reference group was relatively small compared to the number of liquor drinking $K$-ras - rectal cancer cases. Also, liquor was the most frequently consumed beverage type among the male cancer cases and as such, a statistically significant result is more likely to be found for liquor than for beer or wine.

To date, some studies have been performed on the effect of different lifestyle factors on genetic alterations of the K-ras gene (Bautista et al., 1997; Martinez et al., 1999; Slattery et al., 2000, 2001), of which only two considered alcohol consumption (Martinez et al., 1999; Slattery et al., 2000). Martinez et al. (1999), who conducted crosssectional analyses among adenoma patients in a phase III trial, found no associations between total alcohol consumption and $K$-ras gene mutations in adenomas. Slattery et al. (2000), used data collected as part of a large populationbased case-control study on sporadic colon cancer. Without distinguishing between men and women, the authors found that levels of alcohol intake above $10 \mathrm{~g} /$ day reduced the risk of $K$-ras mutations in colon tumors (odds ratio [OR]: $0.7,95 \% \mathrm{CI}: 0.5-1.0)$. None of the above mentioned authors reported on the different types of alcoholic beverages.

\subsection{Alcohol, $C R C$, and type of $K$-ras mutations}

Our data showed no association between beer consumption, independent from alcohol intake, and colon tumors with a $\mathrm{G} \rightarrow$ A mutation in men, whereas a statistically significant increased risk was observed for rectal tumors with a $\mathrm{G} \rightarrow$ A mutation. Again, caution is warranted not to overinterpret this result. The increased risk was based on merely 13 male rectal cancer cases with a $\mathrm{G} \rightarrow \mathrm{A}$ mutation and a reference group of only 7 cases. As mentioned in Section 1 , the adverse effects of elevated NDMA levels present in beer before 1979 might influence the risk of cancer for up to 10 years later. We checked the exact year of cancer diagnosis of the 13 male rectal cancer cases that harbored a $\mathrm{G} \rightarrow$ A mutation; however, only one of these cases was diagnosed between January 1979 and January 1990, namely in 1989. Also, the results in Table 2, based on 22 male $K$ ras + rectal cancer cases and a reference group of 14 cases, indicated that beer, independent of consumed alcohol, was not associated with the risk of rectal tumors harboring a mutated K-ras gene. Unfortunately, we have not been able to gather information on the actual nitrosamine levels that were present in beer over the past few decades, or on whether these concentrations might vary across different types of beer and brands. We therefore will not emphasize the association we observed between beer consumption in men and rectal cancer harboring a $\mathrm{G} \rightarrow$ A mutation too much.

To our knowledge, only one other study reported an association between total alcohol consumption, but not specific beverage types, and different types of $K$-ras mutations (Slattery et al., 2000). In this study, the authors found that levels of alcohol above $10 \mathrm{~g}$ /day were associated with a reduced risk of $\mathrm{G} \rightarrow \mathrm{A}$ mutations in their populationbased case-control study on sporadic colon cancer (OR: $0.7,95 \%$ CI: 0.4-1.1).

\subsection{Strengths and limitations of the study}

This prospective study was based on a large population. Due to record linkage to the NCR and to PALGA, losses to follow-up were minimized. The high completeness of follow-up of cancer incidence and of subcohort members also minimized selection and information bias. Exclusion of cases diagnosed during the first 2.3 years of follow-up, diminished the chance of information bias due to preclinical symptoms of CRC.

Our study is currently the largest prospective study that has investigated associations between alcohol consumption and colon and rectal cancer with and without $K$-ras mutations. Nevertheless, it should be noted that the number of colon and rectal cancer cases in certain subgroups are small.

\subsection{Conclusion}

This study does not show a clear relationship between alcohol consumption and risk of colon and rectal tumors with a $K$-ras mutation, nor was a positive association apparent between beer consumption and the risk of colon and rectal tumors harboring $\mathrm{G} \rightarrow \mathrm{A}$ transitions in the $K$-ras gene. Liquor consumption in men, seemed to be a potential risk factor for developing a $K$-ras - rectal tumor, independent of the alcohol consumed. We conclude that although daily alcohol consumption from a certain level of consumption may be a risk factor for developing CRC, alcohol consumption seems not involved in predisposing to $\mathrm{CRC}$ through (specific) mutations in the K-ras gene. 


\section{Acknowledgments}

Financial support for this study is provided by a grant from the European Research Advisory Board.

We are indebted to the participants of this study and further wish to thank the regional cancer registries (IKA, IKL, IKMN, IKN, IKO, IKR, IKST, IKW, IKZ, and VIKC), and the Netherlands nationwide registry of pathology. We also thank Dr. A. Volovics and Dr. A. Kester for statistical advice; Dr A. de Bruïne for pathological advise; Dr. M. Brink for the collection of tissue samples; financial support for collection of tumor material and mutation analyses was provided by a grant from the Dutch Cancer Society. We thank Dr. L. Schouten, S. van de Crommert, H. Brants, J. Nelissen, C. de Zwart, M. Moll, W. van Dijk, M. Jansen, and A. Pisters for assistance; and H. van Montfort, T. van Moergastel, L. van den Bosch, R. Schmeitz for programming assistance. Finally, we would like to thank all the Dutch pathology laboratories for their cooperation in providing the tissue blocks.

\section{References}

Ahmed, F. E. (1995). Toxicological effects of ethanol on human health. Crit Rev Toxicol 25, 347-367.

Badger, T. M., Ronis, M. J., Seitz, H. K., Albano, E., IngelmanSundberg, M., \& Lieber, C. S. (2003). Alcohol metabolism: role in toxicity and carcinogenesis. Alcohol Clin Exp Res 27, 336-347.

Bautista, D., Obrador, A., Moreno, V., Cabeza, E., Canet, R., Benito, E., Bosch, X., \& Costa, J. (1997). Ki-ras mutation modifies the protective effect of dietary monounsaturated fat and calcium on sporadic colorectal cancer. Cancer Epidemiol Biomarkers Prev 6, 57-61.

Boffetta, P., \& Hashibe, M. (2006). Alcohol and cancer. Lancet Oncol 7, 149-156.

Brink, M., de Goeij, A. F., Weijenberg, M. P., Roemen, G. M., Lentjes, M. H., Pachen, M. M., Smits, K. M., de Bruine, A. P., Goldbohm, R. A., \& van den Brandt, P. A. (2003). K-ras oncogene mutations in sporadic colorectal cancer in The Netherlands Cohort Study. Carcinogenesis 24, 703-710.

Cerottini, J. P., Caplin, S., Saraga, E., Givel, J. C., \& Benhattar, J. (1998). The type of K-ras mutation determines prognosis in colorectal cancer. Am J Surg 175, 198-202.

Cho, E., Smith-Warner, S. A., Ritz, J., van den Brandt, P. A., Colditz, G. A., Folsom, A. R., Freudenheim, J. L., Giovannucci, E., Goldbohm, R. A., Graham, S., Holmberg, L., Kim, D. H., Malila, N., Miller, A. B., Pietinen, P., Rohan, T. E., Sellers, T. A., Speizer, F. E., Willett, W. C., Wolk, A., \& Hunter, D. J. (2004). Alcohol intake and colorectal cancer: a pooled analysis of 8 cohort studies. Ann Intern Med 140, 603-613.
Ellen, G., \& Schuller, P. L. (1983). N-nitrosamine investigations in the Netherlands: highlights from the last ten years, In: R. Preussmann (Ed.), Das Nitrosamin-Problem (pp. 81-92). Weinheim, Germany: Weinheim Verlag.

Fearon, E. R., \& Vogelstein, B. (1990). A genetic model for colorectal tumorigenesis. Cell 61, 759-767.

Jacoby, R. F., Alexander, R. J., Raicht, R. F., \& Brasitus, T. A. (1992). $\mathrm{K}$-ras oncogene mutations in rat colon tumors induced by N-methyl$\mathrm{N}$-nitrosourea. Carcinogenesis 13, 45-49.

Martinez, M. E., Maltzman, T., Marshall, J. R., Einspahr, J., Reid, M. E., Sampliner, R., Ahnen, D. J., Hamilton, S. R., \& Alberts, D. S. (1999). Risk factors for Ki-ras mutation in sporadic colorectal adenomas. Cancer Res 59, 5181-5185.

Salaspuro, M. P. (2003). Alcohol consumption and cancer of the gastrointestinal tract. Best Pract Res Clin Gastroenterol 17, 679-694.

Schoenfeld, D. (1982). Partial residuals for the proportional hazards regression model. Biometrika 69, 239-241.

Seitz, H. K., Matsuzaki, S., Yokoyama, A., Homann, N., Vakevainen, S., \& Wang, X. D. (2001). Alcohol and cancer. Alcohol Clin Exp Res 25 , 137S-143S.

Seitz, H. K., Maurer, B., \& Stickel, F. (2005). Alcohol consumption and cancer of the gastrointestinal tract. Dig Dis 23, 297-303.

Slattery, M. L., Anderson, K., Curtin, K., Ma, K., Schaffer, D., Edwards, S., \& Samowitz, W. (2001). Lifestyle factors and Ki-ras mutations in colon cancer tumors. Mutat Res 483, 73-81.

Slattery, M. L., Curtin, K., Anderson, K., Ma, K. N., Edwards, S., Leppert, M., Potter, J., Schaffer, D., \& Samowitz, W. S. (2000). Associations between dietary intake and Ki-ras mutations in colon tumors: a population-based study. Cancer Res 60, 6935-6941.

Span, M., Moerkerk, P. T., De Goeij, A. F., \& Arends, J. W. (1996). A detailed analysis of K-ras point mutations in relation to tumor progression and survival in colorectal cancer patients. Int $J$ Cancer 69 , 241-245.

Spiegelhalder, B., Eisenbrand, G., \& Preussmann, R. (1979). Contamination of beer with trace quantities of N-nitrosodimethylamine. Food Cosmet Toxicol 17, 29-31.

Stephany, R. W., \& Schuller, P. L. (1980). Daily dietary intakes of nitrate, nitrite and volative N-nitrosamines in the Netherlands using the duplicate portion sampling technique. Oncology 37, 203-210.

Taylor, B., \& Rehm, J. (2005). Moderate alcohol consumption and diseases of the gastrointestinal system: a review of pathophysiological processes. Dig Dis 23, 177-180.

Van den Brandt, P. A., Goldbohm, R. A., van 't Veer, P., Volovics, A., Hermus, R. J., \& Sturmans, F. (1990a). A large-scale prospective cohort study on diet and cancer in The Netherlands. J Clin Epidemiol 43, 285-295.

Van den Brandt, P. A., Schouten, L. J., Goldbohm, R. A., Dorant, E., \& Hunen, P. M. (1990b). Development of a record linkage protocol for use in the Dutch Cancer Registry for Epidemiological Research. Int $J$ Epidemiol 19, 553-558.

Vogelstein, B., Fearon, E. R., Hamilton, S. R., Kern, S. E., Preisinger, A. C., Leppert, M., Nakamura, Y., White, R., Smits, A. M., \& Bos, J. L. (1988). Genetic alterations during colorectal-tumor development. $N$ Engl J Med 319, 525-532. 